\title{
Managing glyphosate-resistant weeds with cover crop associated with herbicide rotation and mixture
}

\section{Manejando plantas daninhas resistentes ao glyphosate com cultura de cobertura associada a rotação e mistura de herbicidas}

\author{
Aroldo Marochi' ${ }^{1}$ Antonio Ferreira ${ }^{2}$, Hudson Kagueyama Takano ${ }^{3 *}$, \\ Rubem Silvério Oliveira Junior ${ }^{4}$, Ramiro Fernando Lopez Ovejero ${ }^{2}$
}

\author{
${ }^{1}$ AgroMarochi, Ponta Grossa, PR, Brasil \\ ${ }^{2}$ Monsato, São Paulo, SP, Brasil \\ ${ }^{3}$ Colorado State University, Fort Collins, CO, United States of America \\ ${ }^{4}$ Universidade Estadual de Maringá/UEM, Maringá, PR, Brasil \\ ${ }^{*}$ Corresponding author: hudsontakano@gmail.com \\ Received in July 4, 2018 and approved in August 20, 2018
}

\begin{abstract}
Herbicide resistance has become a major concern for agricultural systems, and integrating weed management practices seem to be the most promise way for its mitigation. The effects of cropping systems including ruzigrass (Urochloa ruziziensis) associated with herbicide rotation programs were evaluated for the management of glyphosate resistant conyza (Conyza sumatrensis) and sourgrass (Digitaria insularis) in soybean and corn production systems. A 3x3 factorial was evaluated in four consecutive soybean (spring-summer) and corn (fall-winter) double cropping seasons. Factor A consisted of three combinations of cropping systems in the fall-winter: corn, corn plus ruzigrass, and ruzigrass alone. Factor $B$ was based on increasing levels of diversity in herbicide mode of action over the four-year period $(5,8$, and $11 \mathrm{MoAs})$. The results indicate that using ruzigrass significantly increased soil coverage by cover crop residues. In general, the cover crop was more efficient for conyza than for sourgrass control, whereas herbicide programs provided greater control on sourgrass than on conyza. Besides the weed suppression effect, the accumulation of ruzigrass biomass on the soil surface during the fall-winter also improved yield of soybean in the spring-summer. The integration of ruzigrass as a cover crop and the use of herbicide programs with multiple modes of action can provide efficient control of glyphosate-resistant conyza and sourgrass. The use of only one of these strategies was not effective in most cases, especially for the long term.
\end{abstract}

Index terms: Digitaria insularis; Conyza sumatrensis; integrated weed management; Urochloa ruziziensis; herbicide resistance.

\section{RESUMO}

A resistência a herbicidas tem se tornado um dos principais problemas que os produtores têm enfrentado, e as estratégias de manejo integrado de plantas daninhas são as mais importantes ferramentas para a sua mitigação. O objetivo deste trabalho foi investigar o efeito do cultivo de braquiária (Urochloa ruziziensis) associado a diferentes programas de rotação de herbicidas no manejo de buva (Conyza sumatrensis) e capim-amargoso (Digitaria insularis) resistentes ao glyphosate no sistema de produção de soja e milho. Um fatorial $3 \times 3$ foi avaliado durante quatro safras consecutivas de soja no verão e milho no inverno. O Fator A foi constituído de diferentes sistemas de manejo de inverno: milho solteiro, milho integrado com braquiária e braquiária solteira. O Fator foi baseado em programas de rotação de herbicidas com diferentes níveis de diversidade em mecanismos de ação ao longo das quatro safras. O cultivo de braquiária no inverno incrementou significativamente a biomassa residual no solo. Essa cobertura do solo foi mais eficiente para controlar buva do que capimamargoso, embora ambas plantas daninhas foram suprimidas pela cultura de cobertura. O uso de programas com maior rotação de mecanismos de ação de herbicidas foi mais eficiente para controlar capim-amargoso do que buva. $\mathrm{O}$ uso isolado de cultura de cobertura ou de rotação de herbicidas não foi efetivo para o manejo de buva e amargoso. No entanto, integrando essas duas opções de manejo, foi possível controlar efetivamente ambas as espécies resistentes ao glyphosate e consequentemente aumentar a produtividade das culturas.

Termos para indexação: Digitaria insularis; Conyza sumatrensis; manejo integrado de plantas daninhas; Urochloa ruziziensis; resistência a herbicidas.

\section{INTRODUCTION}

In the last decades, Brazil has become one of the largest grain producers in the world (USDA, 2017). This increase in production is mainly due to the use of crop varieties with high yield potential combined with herbicide tolerance and insect resistance traits. Since 2012, more than $90 \%$ of soybean fields in South America have been planted with Roundup Ready (RR) varieties (Peterson et al., 2017). In 2016/17, the average yield per hectare was $3,200 \mathrm{~kg}$ of soybean and $5,400 \mathrm{~kg}$ of corn, 
for a total production of 199.5 billion $\mathrm{kg}$ of these two crops (USDA, 2017).

In the modern Brazilian agriculture, there is a consensus to intensify the production model to obtain higher yields and profitability via crop rotations and best management practices. One example is a production system that alternates soybean with corn, enabling the production of two crops per year in most of the country's grainproducing areas. This cropping system is commonly used in areas such as Paraná, Mato Grosso do Sul, Goiás, and Mato Grosso (Siqueira Neto et al., 2010). In this system, soybean is generally planted in September-November (spring-summer), while corn is planted immediately after soybean harvest between January and March (fall-winter). Corn residue degrades quickly, especially in areas with predominant high temperatures such as the Central-West region of Brazil. This significantly impacts the influence of crop residue as a tool for suppressing weed emergence (Davis, 2010).

The main glyphosate-resistant (GR) weeds in Brazil include sourgrass (Digitaria insularis), a perennial species, and the complex of Conyza species (Conyza canadensis, C. bonariensis, and C. sumatrensis - herein referred as conyza), all annual species. These weed species are of great importance to the soybean-corn production system and are found throughout most regions of the country (Lopez Ovejero et al., 2017; Santos et al., 2014). In the case of soybean, the potential yield loss due to weed interference can be as much as $64 \%$ for sourgrass and $55 \%$ for conyza (Oliveira Neto et al., 2010; Gemelli et al., 2012). The complex formed by the conyza species is estimated to extend to 10.6 million ha. Similarly, the infested area with sourgrass is estimated to be 8.2 million ha (Lopez Ovejero et al., 2017). In this grass species, biotypes that are also resistant to ACCase inhibitors have been identified (Heap, 2018). Regarding to conyza, biotypes that are resistant to ALS inhibitors, photosystem I inhibitors, and PPO inhibitors have already been reported in Brazil (Santos et al., 2014; Heap, 2018). Thus, these species commonly infest the same areas concurrently, making their management more complex. This is mainly because the efficacy of available strategies, most of them including tank mixtures, is affected by incompatibility among product formulations and antagonism between herbicides.

For a consistent management of these weeds, considering cost-effective long-term production systems, including management tools such as cover crops and herbicide rotation (Chikowo et al., 2009), is crucial. Ruzigrass (Urochloa ruziziensis, Germ \& Evrard) is a tropical grass that is used for animal feed, but also has been used as a cover crop in winter, as a single crop, or intercropped with corn as second crop (Oliveira Junior et al., 2014). Corn cultivation intercropped with ruzigrass, when properly managed, provides physicochemical benefits and covers the soil with biomass, contributing significantly to weed suppression without interfering with corn yield (Baldé et al., 2011). In this cropping system, ruzigrass is managed as an annual plant and grown with the purpose of providing soil coverage during the period between corn harvest and soybean planting (Borghi et al., 2008). Using ruzigrass as a cover crop usually provides up to 3.5 ton ha ${ }^{-1}$ of dry mass after burndown prior to sowing (Oliveira Junior et al., 2014). Ruzigrass can also suppress weed growth when grown alone or when intercropped with corn. In addition, weed suppression provided by this grass is not limited to the biomass physical effect but can also due to allelopathic compounds with suppressive effect on weed emergence that have been identified (Paiva-Foletto et al., 2012).

Several factors contribute to the selection of herbicide-resistant weeds; however, using one herbicide as a single weed management tool is the main factor for selection pressure of resistant biotypes (Norsworthy et al., 2012). In turn, herbicide rotations or combinations with different mechanisms of action, as well as using cover crops, whether cultivated alone or intercropped, are essential tools to reduce selection pressure for resistant biotypes (Beckie, 2011; Norsworthy et al., 2012).

In this context, the hypothesis of this study is that within a profitable crop-rotation system, ruzigrass cultivation as a cover crop, combined with different herbicide strategies (mixture and rotation) is effective for GR conyza and sourgrass management. Few studies have quantified the benefits of ruzigrass and diverse herbicide programs in managing resistance. Therefore, the objective of this research was to evaluate the effects of different ruzigrass cultivation systems in combination with different herbicide rotation and tank mixtures on conyza and sourgrass management in a soybean/corn production system in Brazil.

\section{MATERIAL AND METHODS}

Field experiments were conducted in Francisco Alves, Paraná, Brazil (2406'12.64”'S; 5354'27.54”W; $312 \mathrm{~m}$ altitude). For four consecutive years, soybean was planted (spring-summer) followed by corn (fall-winter) between October 2012 and July 2016, to evaluate the effect of ruzigrass and different herbicide programs on GR 
conyza and sourgrass management. Glyphosate resistance in conyza and sourgrass in this field was confirmed in our previous research, in which both species were not controlled with the glyphosate discriminatory rate of 960 $\mathrm{g}$ ae ha ${ }^{-1}$ (Lopez Ovejero et al., 2017).

The experimental area was under a no-tillage system for the past 14 years, with successive soybean (spring/summer) followed by corn (fall/winter) cultivation in the previous seven years. Roundup Ready ${ }^{\circledR}$ soybean varieties had been used in this area for the last 10 years. The soil from the experimental area was a sandy-clay loam with $\mathrm{pH} 6$ and $3.1 \%$ organic matter.

Plots dimensions were $20 \mathrm{~m}$ long by $12 \mathrm{~m}$ wide. The experimental design was randomized complete block with three replications. Treatments were arranged in a $3 \times 3$ factorial. The Factor A was consisted of three different herbicide programs, whereas Factor B was consisted of three different cropping systems (CS). The herbicide programs (Factor A) contained increasing number of different mechanisms of action used over the four years of study: $5 \mathrm{MoA}, 8 \mathrm{MoA}$, and $11 \mathrm{MoA}$ (Table 1; Table 2). The cropping systems (Factor B) encompassed corn alone (CS1), corn intercropped with ruzigrass (CS2) and ruzigrass alone (CS3) only in the first fall/ winter (Table 3). For the second, third and fourth fall/ winter seasons, corn alone was planted in CS1 and corn intercropped with ruzigrass was cultivated in CS2 and CS3. Ruzigrass seeding was broadcast after POST** application at $20 \mathrm{~kg}$ seeds ha-1 for all cropping systems. The cultural value for the ruzigrass seeds was $76 \%$. Soybean was always the crop cultivated in the spring/summer for all treatments. For all years the soybean variety and corn hybrid were BMX Vmax and DKB330 Pro, respectively.

Before the experiments were established, conyza density was 58.2 plants $\mathrm{m}^{-2}$ with 2 - to 35 -cm-height stage, whereas sourgrass density was 16.7 plants $\mathrm{m}^{-2}$, with plants ranging from five tillers to flowering. All herbicide applications were performed using a $\mathrm{CO}_{2}$-pressurized backpack sprayer with $2 \mathrm{~m}$-boom equipped with XR 11002 flat fan nozzles, spaced at $0.50 \mathrm{~m}$ calibrated to deliver a carrier volume of $200 \mathrm{~L} \mathrm{ha}^{-1}$ The dates for planting, spraying, and evaluation are presented in Table 4.

Weed control was evaluated at the end of each cropping cycle using visual scale of $0-100 \%$, where $0 \%$ meant no symptoms and $100 \%$ represented plant death. In addition, weeds were counted on three random samplings of $1 \mathrm{~m}^{2}$ per plot. Dry biomass production was also evaluated immediately after each harvest, by sampling occurring three $1 \mathrm{~m}^{2}$ points per plot. To evaluate crop's yield, plants were harvested manually; these plants were then threshed, grains were weighed, and moisture was

Table 1: Herbicide common and trade names and respective rates used in all experiments.

\begin{tabular}{cccc}
\hline Common name & Trade name & Herbicide rate $\left(\mathrm{g}\right.$ ai or ae ha $\left.{ }^{-1}\right)$ & Manufacturer $^{1}$ \\
\hline [paraquat+diuron] & Gramocil & {$[400+200]$} & Syngenta Crop Protection \\
2,4-D & DMA 806 BR & 1255 & Dow AgroSciences \\
atrazine & Proof & 1500 & Syngenta Crop Protection \\
clethodim & Select & 108 & Arysta LifeScience \\
cloransulam & Pacto & 35 & Dow AgroSciences \\
diclosulam & Spider & 38 & Dow AgroSciences \\
flumioxazin & Flumyzin & 60 & Ihara Chemical Industry \\
glyphosate & Roundup Transorb & 1080 & Monsanto Company \\
haloxyfop & Verdict & 120 & Dow AgroSciences \\
imazethapyr & Vezir & 106 & BASF Agriculture Solutions \\
nicosulfuron & Sanson & 30 & Syngenta Crop Protection \\
s-metolachlor & Dual Gold & 1920 & Syngenta Crop Protection \\
tembotrione & Soberan & 84 & Bayer CropScience \\
\hline
\end{tabular}

${ }^{1}$ Syngenta Crop Protection, Greensboro, NC; http://www.syngentacropprotection.coma AG; Dow AgroSciences, Indianapolis, IN; http://www.dowagro.com; Arysta LifeScience, Cary, NC, https://www.arystalifescience.com/; Ihara Chemical Industry, Tokyo, Japan, http://www.iharachem.co.jp/; Monsanto Company, Saint Louis, MO, https://monsanto.com/; BASF Corporation Agricultural Products, Research Triangle Park, NC, https://www.basf.com/; Bayer CropScience, Monheim am Rhein, Germany, https://www.cropscience.bayer.com. 
Table 2: Herbicide programs (\# MoA) across a 4-year study with cover crop and herbicide rotation and mixture for weed resistance management.

\begin{tabular}{|c|c|c|c|c|}
\hline \multirow{2}{*}{ Season } & \multirow{2}{*}{ Application } & \multicolumn{3}{|c|}{ Herbicide Programs } \\
\hline & & $5 \mathrm{MoA}$ & $8 \mathrm{MoA}$ & $11 \mathrm{MoA}$ \\
\hline \multirow{3}{*}{$\begin{array}{l}\text { Spring-Summer } \\
2012 / 13\end{array}$} & Burndown 1 & gly+2,4D+cle & gly+2,4D+cle & gly+2,4D+cle \\
\hline & Burndown 2 & [par+diu] & [par+diu]+s-met & {$[p a r+d i u]+i m a$} \\
\hline & POST & gly & gly+cle & gly+cle \\
\hline \multirow{2}{*}{$\begin{array}{l}\text { Fall-Winter } \\
2013\end{array}$} & Burndown & gly+cle & gly+cle & gly+cle \\
\hline & POST** & atr & atr & $\mathrm{atr}+2,4 \mathrm{D}$ \\
\hline \multirow{3}{*}{$\begin{array}{c}\text { Spring-Summer } \\
2013 / 14\end{array}$} & Burndown 1 & gly+2,4D+cle & gly+2,4D+cle & gly+2,4D+cle \\
\hline & Burndown 2 & par & {$[p a r+d i u]+d i c$} & [par+diu]+s-met \\
\hline & POST & gly & gly+cle & gly+cle \\
\hline $\begin{array}{l}\text { Fall-Winter } \\
2014\end{array}$ & POST** & gly+atr & gly+atr & glu+atr \\
\hline \multirow{3}{*}{$\begin{array}{l}\text { Spring-Summer } \\
2014 / 15\end{array}$} & Burndown 1 & gly+2,4D+cle & gly+2,4D+cle & gly+2,4D+cle \\
\hline & Burndown 2 & par & glu+s-met & {$[p a r+d i u]+f l u$} \\
\hline & POST & gly & gly+cle & gly+cle \\
\hline \multirow{2}{*}{$\begin{array}{l}\text { Fall-Winter } \\
2015\end{array}$} & Burndown & gly+cle & gly+cle & gly+cle \\
\hline & POST** & gly+atr & gly+atr & nic+atr \\
\hline \multirow{3}{*}{$\begin{array}{l}\text { Spring-Summer } \\
2015 / 16\end{array}$} & Burndown 1 & gly+2,4D & gly+2,4D+hal & gly+2,4D+cle \\
\hline & Burndown 2 & par & {$[p a r+d i u]+f l u$} & glu+flu+tri \\
\hline & POST & gly+hal & gly+cle+clo & gly+hal+clo \\
\hline \multirow{2}{*}{$\begin{array}{l}\text { Fall-Winter } \\
\quad 2016\end{array}$} & Burndown & gly & gly+hal & gly+cle \\
\hline & POST** & gly+atr & nic+atr & tem+atr \\
\hline
\end{tabular}

*gly = glyphosate; cle = clethodim; par = paraquat; diu = diuron; ima = imazethapyr; 2,4D = 2,4-D; s-met = s-metolachlor; atr = atrazine; tem = tembotrione; tri = trifluralin; dic = diclosulam; flu = flumioxazin; nic = nicosulfuron; clo = cloransulam; hal = haloxyfop. **POST=Post-emergence in corn but not for ruzigrass.

Table 3: Crop systems (CS) across a 4-year study with cover crop and herbicide programs for weed resistance management.

\begin{tabular}{cccc}
\hline Season & \multicolumn{3}{c}{ Cropping System } \\
\cline { 2 - 4 } & CS1 ${ }^{*}$ & CS2 & CS3 \\
\hline Spring-Summer 2012/13 & Soybean & Soybean & Soybean \\
Fall-Winter 2013 & Corn & Corn + ruzigrass & Ruzigrass \\
\hline Spring-Summer 2013/14 & Soybean & Soybean & Soybean \\
Fall-Winter 2014 & Corn & Corn + ruzigrass & Corn + ruzigrass \\
\hline Spring-Summer 2014/15 & Soybean & Soybean & Soybean \\
Fall-Winter 2015 & Corn & Corn + ruzigrass & Corn + ruzigrass \\
\hline Spring-Summer 2015/16 & Soybean & Soybean & Soybean \\
Fall-Winter 2016 & Corn & Corn + ruzigrass & Corn + ruzigrass \\
\hline
\end{tabular}

*CS: cropping system; Corn + ruzigrass: species were grown at the same area (intercropping). 
Table 4: Calendar of applications, sowing dates, evaluations and crop harvesting across a 4-year study with cover crop and herbicide programs for weed resistance management.

\begin{tabular}{|c|c|c|}
\hline Season & Date & Operation \\
\hline \multirow{6}{*}{$\begin{array}{l}\text { Spring-Summer } \\
2012 / 13\end{array}$} & $29 / 09 / 2012$ & Burndown 1 application \\
\hline & $18 / 10 / 2012$ & Burndown 2 application \\
\hline & $16 / 10 / 2012$ & Sowing \\
\hline & $17 / 11 / 2012$ & POST application \\
\hline & $13 / 02 / 2013$ & Weed control evaluation \\
\hline & $20 / 02 / 2013$ & Harvest \\
\hline \multirow{6}{*}{$\begin{array}{l}\text { Fall-Winter } \\
2013\end{array}$} & $19 / 02 / 2013$ & Burndown application \\
\hline & $01 / 03 / 2013$ & Corn sowing \\
\hline & 28/03/2013 & POST application \\
\hline & 03/04/2013 & Ruzigrass broadcast sowing \\
\hline & $10 / 04 / 2013$ & 2,4-D application on ruzigrass \\
\hline & 05/08/2013 & Weed control evaluation and harvest \\
\hline \multirow{5}{*}{$\begin{array}{c}\text { Spring-Summer } \\
2013 / 14\end{array}$} & $10 / 09 / 2013$ & Burndown 1 application \\
\hline & $11 / 10 / 2013$ & Burndown 2 application \\
\hline & $12 / 10 / 2013$ & Sowing \\
\hline & $11 / 11 / 2013$ & POST application \\
\hline & $16 / 02 / 2013$ & Weed control evaluation and harvest \\
\hline \multirow{3}{*}{$\begin{array}{l}\text { Fall-Winter } \\
\quad 2014\end{array}$} & $26 / 02 / 2014$ & Corn and ruzigrass sowing \\
\hline & $23 / 03 / 2014$ & POST application \\
\hline & $12 / 08 / 2014$ & Weed control evaluation and harvest \\
\hline \multirow{5}{*}{$\begin{array}{l}\text { Spring-Summer } \\
2014 / 15\end{array}$} & $17 / 09 / 2014$ & Burndown 1 application \\
\hline & $14 / 10 / 2014$ & Burndown 2 application \\
\hline & $14 / 10 / 2014$ & Sowing \\
\hline & $18 / 11 / 2014$ & POST application \\
\hline & 05/02/2015 & Weed control evaluation and harvest \\
\hline \multirow{4}{*}{$\begin{array}{l}\text { Fall-Winter } \\
\quad 2015\end{array}$} & $15 / 02 / 2015$ & Burndown application \\
\hline & $24 / 02 / 2015$ & Corn and ruzigrass sowing \\
\hline & $21 / 03 / 2015$ & POST application \\
\hline & $27 / 08 / 2015$ & Weed control evaluation and harvest \\
\hline \multirow{5}{*}{$\begin{array}{l}\text { Spring-Summer } \\
2015 / 16\end{array}$} & $07 / 10 / 2015$ & Burndown 1 application \\
\hline & $10 / 10 / 2015$ & Burndown 2 application \\
\hline & 09/10/2015 & Sowing \\
\hline & $14 / 11 / 2015$ & POST application \\
\hline & $10 / 02 / 2016$ & Weed control evaluation and harvest \\
\hline \multirow{4}{*}{$\begin{array}{l}\text { Fall-Winter } \\
2016\end{array}$} & $17 / 02 / 2016$ & Burndown application \\
\hline & $27 / 02 / 2016$ & Corn and ruzigrass sowing \\
\hline & $25 / 03 / 2016$ & POST application \\
\hline & $15 / 08 / 2016$ & Weed control evaluation and harvest \\
\hline
\end{tabular}




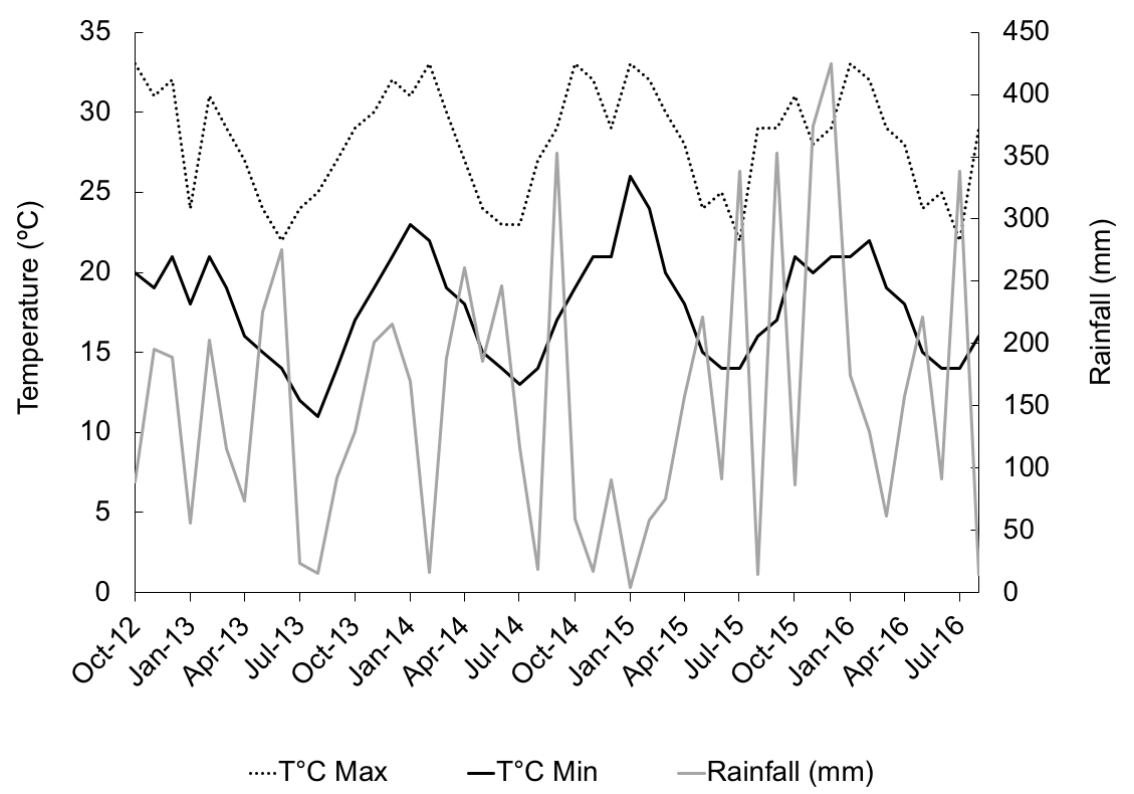

Figure 1: Temperature $\left(\mathrm{T}^{\circ} \mathrm{C} \max , \mathrm{T}^{\circ} \mathrm{C} \mathrm{min}\right)$ and rainfall $(\mathrm{mm})$ data across a 4-year study with crop and herbicide programs for weed resistance management.

adjusted to $13 \%$. Temperatures and rainfall across the period of the experiments are presented in Figure 1.

The statistical analysis was performed using the software Sisvar (UFLA, Lavras, MG, Brazil) (Ferreira 2011). Data passed for variance homogeneity (Levene) and normality (Shapiro-Wilk) tests. All collected data were analyzed with ANOVA to test for significant main effects and interactions. Cropping system and herbicide treatment were considered fixed effect, whereas replication and year were treated as random effects. Where the ANOVA indicated significant differences, means were separated with Fisher's protected LSD at $\alpha=0.05$. Means of the isolated main effects (cropping system and herbicide programs) over time were also represented using nonparametric statistics.

\section{RESULTS AND DISCUSSION}

The analysis of variance showed significant differences among treatments for all variables, except for conyza control in the first soybean cycle (2012/13). These results were expected because the herbicides used in this first soybean cycle were the same for all treatments. The interaction between cropping systems and herbicide programs was also significant for most of the years and variables.

In fall-winter 2013, biomass yield in treatments with ruzigrass was $3,800 \mathrm{~kg} \mathrm{ha}^{-1}$ greater than in treatments without cover crop, which corresponds to two times the residual biomass compared to the preceding crop (Table 5). Intercropping ruzigrass and corn produced $600 \mathrm{~kg} \mathrm{ha}^{-1}$ less biomass than ruzigrass alone. In general, for subsequent crops, treatments with 8 or 11 different modes of action as well as in those with ruzigrass alone or intercropped with corn in the winter, biomass production was similar or higher than when corn was planted alone or when no herbicide diversity was employed. Similar biomass yield was observed in other research for corn intercropped with ruzigrass, and this amount of cover crop residual provided more than $90 \%$ suppression on weed germination (Borghi et al., 2008).

For sourgrass control, treatments with ruzigrass in the fall-winter and with herbicide programs that contained 8 and 11 MoA provided the greatest control over all crops (Table 6). The cropping system with low herbicide diversity (5 MoA) exhibited high levels of control until 2013/14 season; however, from 2014 forward, the control observed with this treatment was not consistent, especially through soybean cultivation. The use of corn intercropped with ruzigrass (CS2) in fall/winter, combined with greater herbicide diversity ( $8 \mathrm{MoA}$ and $11 \mathrm{MoA}$ ), also provided good control throughout all crops. Nevertheless, ruzigrass alone (CS3) provided higher weed suppression than when intercropped with corn. Treatments without ruzigrass in the fall/winter were not efficient for sourgrass control, especially in 2014 and 2016. In agreement with this research, other studies with several weed species have also shown that the use of cover crops is not only effective in suppressing 
Table 5: Crop biomass residue yield $\left(\mathrm{kg} \mathrm{ha}^{-1}\right)$ across a 4-year study with crop and herbicide programs for weed resistance management.

\begin{tabular}{|c|c|c|c|c|c|c|c|c|}
\hline \multirow[b]{2}{*}{$\begin{array}{c}\text { Herbicide } \\
\text { Program }\end{array}$} & \multicolumn{8}{|c|}{ Crop biomass residue yield* } \\
\hline & $\begin{array}{l}\text { Spring/ } \\
\text { Summer } \\
2012 / 13\end{array}$ & $\begin{array}{l}\text { Fall/Winter } \\
2013\end{array}$ & $\begin{array}{l}\text { Spring/ } \\
\text { Summer } \\
2013 / 14\end{array}$ & $\begin{array}{l}\text { Fall/Winter } \\
2014\end{array}$ & $\begin{array}{l}\text { Spring/ } \\
\text { Summer } \\
2014 / 15\end{array}$ & $\begin{array}{l}\text { Fall/Winter } \\
2015\end{array}$ & $\begin{array}{l}\text { Spring/ } \\
\text { Summer } \\
2015 / 16\end{array}$ & $\begin{array}{l}\text { Fall/Winter } \\
2016\end{array}$ \\
\hline & \multicolumn{8}{|c|}{$\mathrm{kg} \mathrm{ha}^{-1}$} \\
\hline & Soybean & Corn & Soybean & Corn & Soybean & Corn & Soybean & Corn \\
\hline $5 \mathrm{MoA}$ & $2536 \mathrm{bA}$ & $3865 \mathrm{aC}$ & 859 cC & $4678 \mathrm{aB}$ & 723 bB & 2256 bB & 888 bA & $2393 \mathrm{aB}$ \\
\hline $8 \mathrm{MoA}$ & 3226 aA & $3827 \mathrm{aC}$ & 1294 bC & $4795 \mathrm{aB}$ & $1702 \mathrm{aA}$ & $2323 \mathrm{bB}$ & 932 bB & $2497 \mathrm{aB}$ \\
\hline \multirow[t]{2}{*}{$11 \mathrm{MoA}$} & $3263 \mathrm{aA}$ & $3890 \mathrm{aC}$ & $1475 \mathrm{aC}$ & $4490 \mathrm{aB}$ & 1729 aA & $2889 \mathrm{aB}$ & $1454 \mathrm{aB}$ & $2268 \mathrm{aB}$ \\
\hline & Soybean & $\begin{array}{c}\text { Corn + } \\
\text { ruzigrass }\end{array}$ & Soybean & $\begin{array}{c}\text { Corn + } \\
\text { ruzigrass }\end{array}$ & Soybean & $\begin{array}{c}\text { Corn + } \\
\text { ruzigrass }\end{array}$ & Soybean & $\begin{array}{c}\text { Corn + } \\
\text { ruzigrass }\end{array}$ \\
\hline $5 \mathrm{MoA}$ & $2720 \mathrm{bA}$ & $7049 \mathrm{aB}$ & $1480 \mathrm{bB}$ & $7517 \mathrm{bA}$ & $1758 \mathrm{aA}$ & $3180 \mathrm{bA}$ & 832 bA & $5587 \mathrm{bA}$ \\
\hline $8 \mathrm{MoA}$ & 3291 aA & $7095 \mathrm{aB}$ & $1644 \mathrm{aB}$ & $7385 \mathrm{bA}$ & $1860 \mathrm{aA}$ & $3690 \mathrm{aA}$ & $1374 \mathrm{aA}$ & $6106 \mathrm{aA}$ \\
\hline \multirow[t]{2}{*}{$11 \mathrm{MoA}$} & 3278 aA & $7171 \mathrm{aB}$ & $1643 \mathrm{aB}$ & $8165 \mathrm{aA}$ & $1831 \mathrm{aA}$ & 3724 aA & $1474 \mathrm{aB}$ & 5967 aA \\
\hline & Soybean & ruzigrass & Soybean & $\begin{array}{c}\text { Corn + } \\
\text { ruzigrass }\end{array}$ & Soybean & $\begin{array}{c}\text { Corn + } \\
\text { ruzigrass }\end{array}$ & Soybean & $\begin{array}{c}\text { Corn + } \\
\text { ruzigrass }\end{array}$ \\
\hline $5 \mathrm{MoA}$ & $2638 \mathrm{bA}$ & 7685 aA & $1851 \mathrm{aA}$ & 7929 aA & $1811 \mathrm{aA}$ & 3089 bA & $1031 \mathrm{bA}$ & $5490 \mathrm{bA}$ \\
\hline $8 \mathrm{MoA}$ & 3257 aA & 7668 aA & $1847 \mathrm{aA}$ & 7980 aA & $1939 \mathrm{aA}$ & 3811 aA & $1458 \mathrm{aA}$ & $6056 \mathrm{aA}$ \\
\hline $11 \mathrm{MoA}$ & 3124 aA & $7711 \mathrm{aA}$ & $1809 \mathrm{aA}$ & $8118 \mathrm{aA}$ & $1915 \mathrm{aA}$ & 3531 aA & $1669 \mathrm{aA}$ & 5999 aA \\
\hline
\end{tabular}

*Means followed by the same lowercase letters for herbicide program and uppercase letters for cropping system do not differ by Fisher's LSD test $(p<0.05)$.

weed emergence but also in reducing weed seed bank in the soil (Brennan; Smith, 2005; Peachey et al., 2002).

During the 4-year study, sourgrass infestation was lower in treatments with corn intercropped with ruzigrass and even lower for ruzigrass-alone treatments in the fall-winter, compared to the treatment with no herbicide diversity and without ruzigrass cultivation (Figure 2). However, the use of herbicide rotation and mixture associated with corn intercropped with ruzigrass and ruzigrass alone maintained sourgrass infestation at extremely low levels. Herbicide rotation and mixture by itself, without ruzigrass, was not effective controlling sourgrass. On the other hand, ruzigrass alone associated with higher herbicide diversity, provided $100 \%$ control on conyza and sourgrass, which demonstrates the suppression effect on weeds afforded by the formation of greater biomass amounts in these treatments (CS2 and CS3). Similar results were reported by Castagnara et al. (2011) who observed $50 \%$ suppression on conyza emergence when ruzigrass was planted at $22.5 \mathrm{~kg} \mathrm{ha}^{-1}$. The weed suppressor effect provided by ruzigrass biomass is beyond the physic soil coverage since natural compounds have been identified in ruzigrass extracts with negative effect on weed germination (Paiva-Foletto et al., 2012).

The results for conyza control showed that prior to the establishment of the system with ruzigrass in the fall/winter, all treatments provided similar control of this species (70-73\%) (Table 7). Starting in fall/winter 2013 , treatments with ruzigrass alone associated with herbicide diversity programs ( $8 \mathrm{MoA}$ and $11 \mathrm{MoA})$ completely controlled this weed until the end of the experiment in 2016. Nevertheless, treatments with no herbicide rotation were effective only for the two crops following cultivation of ruzigrass alone in 2014 and 2015. Treatments including corn and ruzigrass showed less consistent efficacy than those with ruzigrass alone. The last one showed high levels of conyza control until the end of the experiment in 2016. Ruzigrass intercropped with corn in the fall-winter with no herbicide diversity was not effective for managing glyphosate-resistant conyza, suggesting that this cropping system requires weed control complementation with herbicide rotation and mixture. Densities of conyza plants throughout the experiment indicate that herbicide diversity programs 


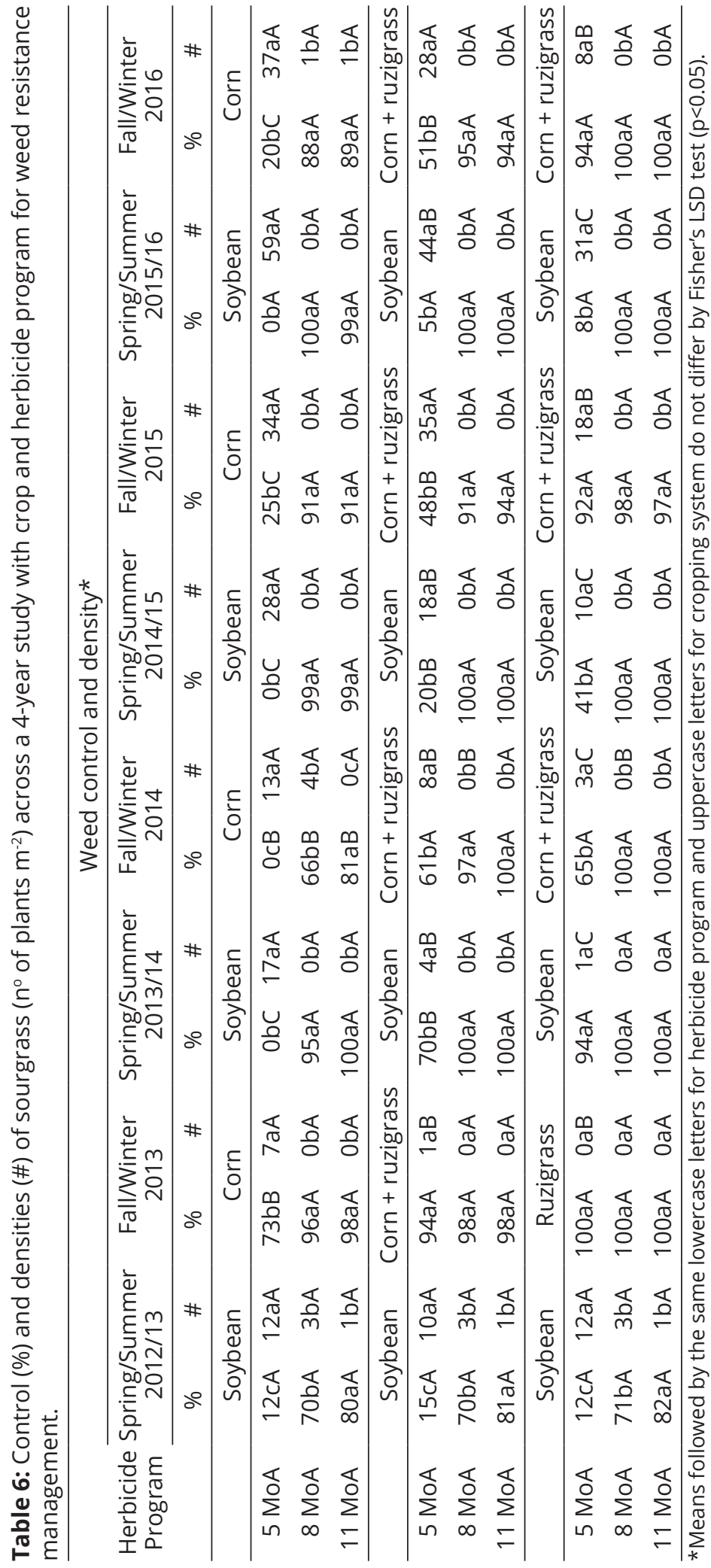


combined with cultivation of ruzigrass alone is the best option for managing this species (Figure 3). By contrast, herbicide rotation and mixture without ruzigrass in the fall/winter was also not sufficient for the effective control of this species. Greater conyza infestations were observed for treatments with no herbicide rotation and no use of ruzigrass in the fall/winter. In general, the use of ruzigrass as a cover crop was more effective in suppressing conyza than sourgrass. This is mainly because conyza emerges in colder months of the year (May-August), when ruzigrass is already established, whereas sourgrass can emerge throughout the year when soil moisture is present. Moreover, these species have different life cycles, as sourgrass is a perennial plant,

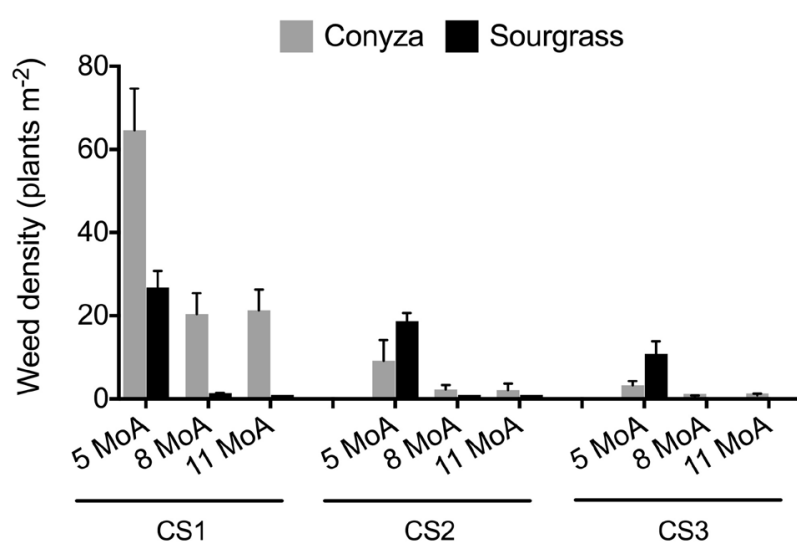

Figure 2: Average densities of sourgrass and conyza across a 4-year study with crop and herbicide programs with increasing number of MoAs for weed resistance management. CS1, CS2 and CS3: cropping system with corn alone, corn intercropped with ruzigrass, and ruzigrass alone in the first fall/winter, respectively.

whereas conyza completes its cycle annually (Gemelli et al., 2013; Marochio et al., 2017).

When analyzing the effects of isolated factors (cropping system and herbicide programs), ruzigrass cultivation in the fall-winter, either alone or intercropped with corn, was extremely effective in controlling conyza (Figure 3). For sourgrass, the use of ruzigrass suppressed emergence of this weed, especially when the cover crop was grown alone. Herbicide diversity programs had a significant effect on management of these two weeds, especially sourgrass (Figure 4). Throughout the experimental period, treatments with herbicide rotation led to lower infestations than treatments with low herbicide diversity. Furthermore, at the end of the experiment, the infestation of both species was almost zero in treatments with herbicide rotation, suggesting that this is an effective tool for weed management. In accordance to these findings, resistance frequency models show that herbicide mixing and rotation of herbicides with different mechanisms of action are effective in delaying herbicide resistance (HR) evolution (Powles et al., 1997; Diggle; Neve; Smith, 2003; Beckie, 2006).

In the first soybean year (2012/13), grain yield was greater for treatments with the highest levels of herbicide diversity programs (11 MoA) (Table 8). No difference was observed among treatments in the fall-winter of 2013, but higher yields were observed in 2013/14 soybean crop for treatments that ruzigrass was cultivated in fall-winter. Moreover, from that crop onward, greater yields were observed for treatments with higher levels of herbicide rotation and mixture, associated with ruzigrass cultivation in the fall-winter, especially due to better weed control afforded by herbicides and by biomass formation. Corn yield was not affected by interference or competition with the intercropping ruzigrass in any year. In addition to the effects of biomass on weed emergence, the biomass accumulation on the soil surface have additional benefits such as lower evapotranspiration, greater water availability, and nutrient recycling. These benefits have been proven to be beneficial for yield improvement in corn and soybean (Baschea et al., 2016).

Conyza and sourgrass are considered the two most important weeds in Brazil because they have evolved resistance to several herbicides (Trezzi et al., 2015; Lopez Ovejero et al., 2017). The evolution of HR is often attributed to limited use of herbicide rotation and mixing and to repeated use of the same mechanism of action (Beckie; Reboud, 2009). Mitigating HR depends on reducing selection pressure by diversifying weed control techniques. Among these strategies, minimizing the spread of resistance genes via pollen or the dispersal of propagules and eliminating increases in the soil's seed bank are extremely important (Norsworthy et al., 2012). In the case of sourgrass, for example, the rapid spread of resistance in South American countries is related to dispersal of resistance genes by wind and combines traffic and also to independent selections due to successive applications of glyphosate (Takano et al., 2018). Thus, as we demonstrated in this research, herbicide rotation and tank mixture, as well as the use of cover crops, are essential for resistance management and prevention of multiple resistant biotypes selection. 


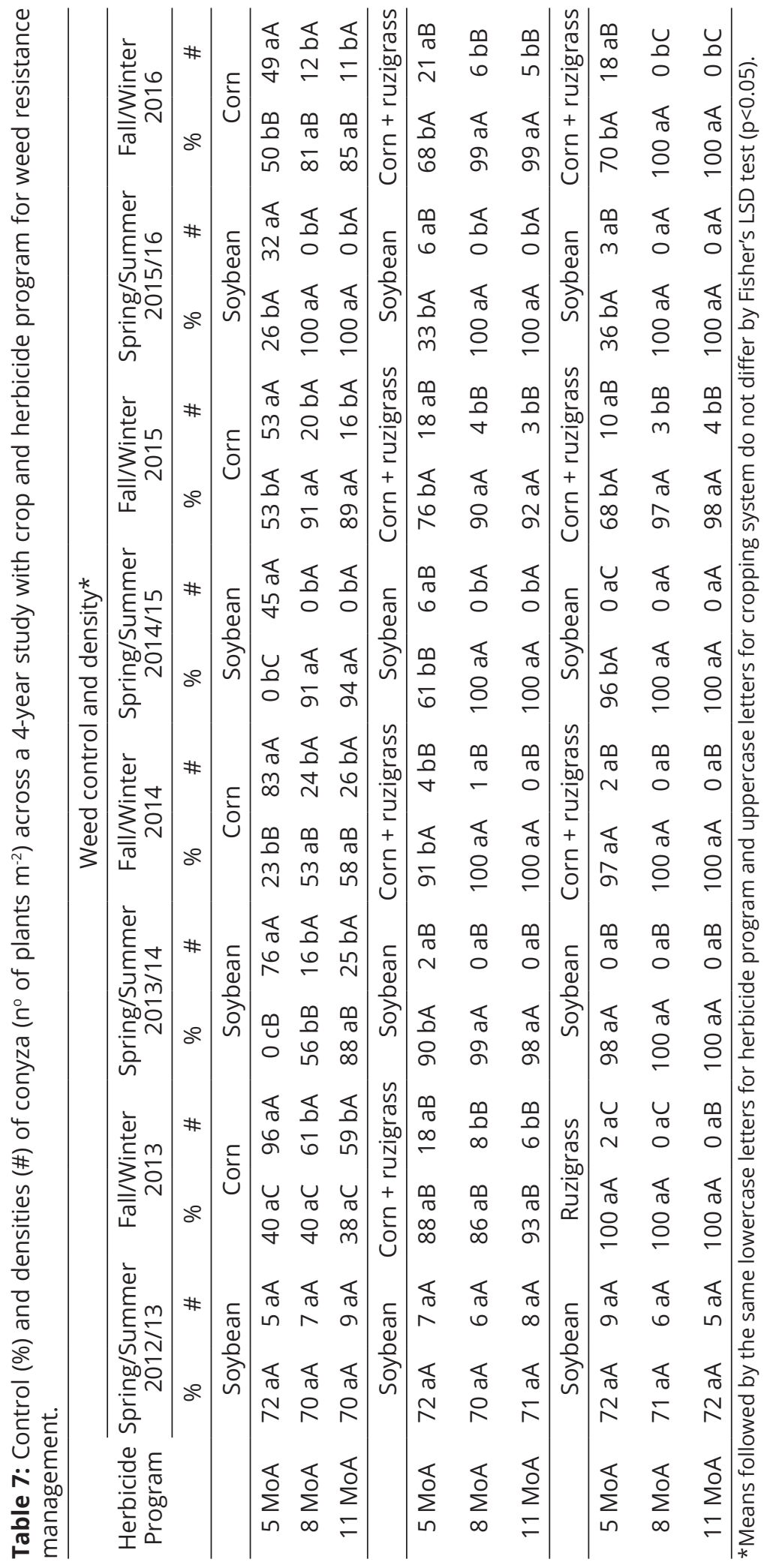


The results of this study provide evidence that using ruzigrass as cover crop results in greater accumulation of biomass, leading to suppression of weed emergence (Tables 5, 6 and 7). These benefits that winter crop provides are usually reflected in increased spring/summer crop yields. Furthermore, yield of corn intercropped with ruzigrass was similar to that achieved with corn alone, indicating that ruzigrass did not interfere in crop yield.
In addition, many chemical management systems, with herbicides applied before and after emergence, alone or in combination with different mechanisms of action were evaluated. Herbicide rotation and mixing were effective in controlling both weed species, especially sourgrass. When appropriate management with herbicides was used, weed density was kept in very low levels (Figure 4). However, long-term management of these weed species should
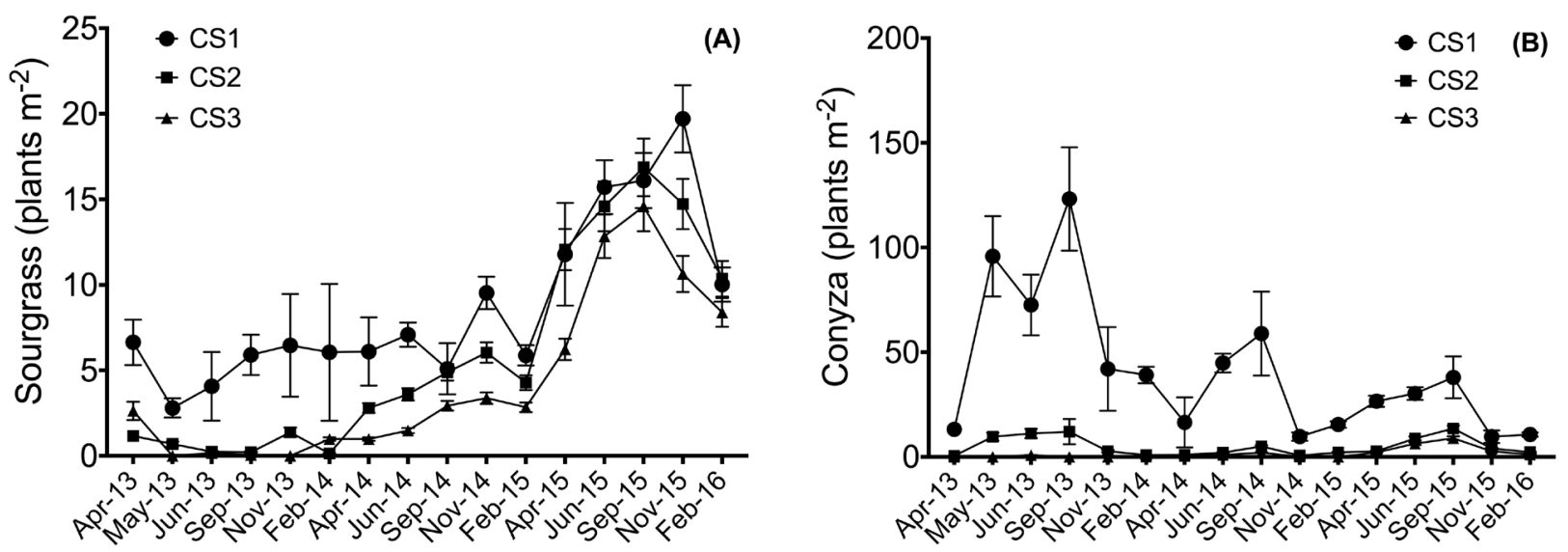

Figure 3: Average densities of sourgrass (A) and conyza (B) across a 4-year study with cropping systems for weed resistance management. CS1, CS2 and CS3: cropping system with corn alone, corn intercropped with ruzigrass, and ruzigrass alone in the first fall/winter, respectively.
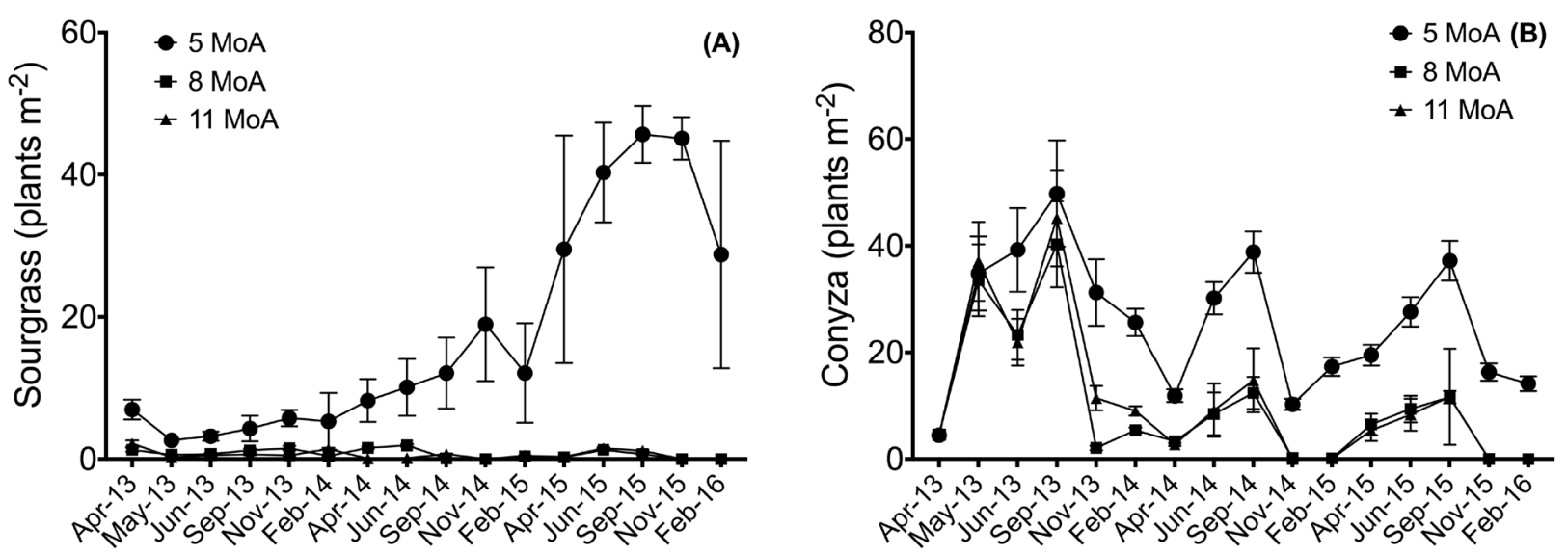

Figure 4: Average densities of sourgrass (A) and conyza (B) across a 4-year study with herbicide programs with increasing number of MoAs for weed resistance management. 


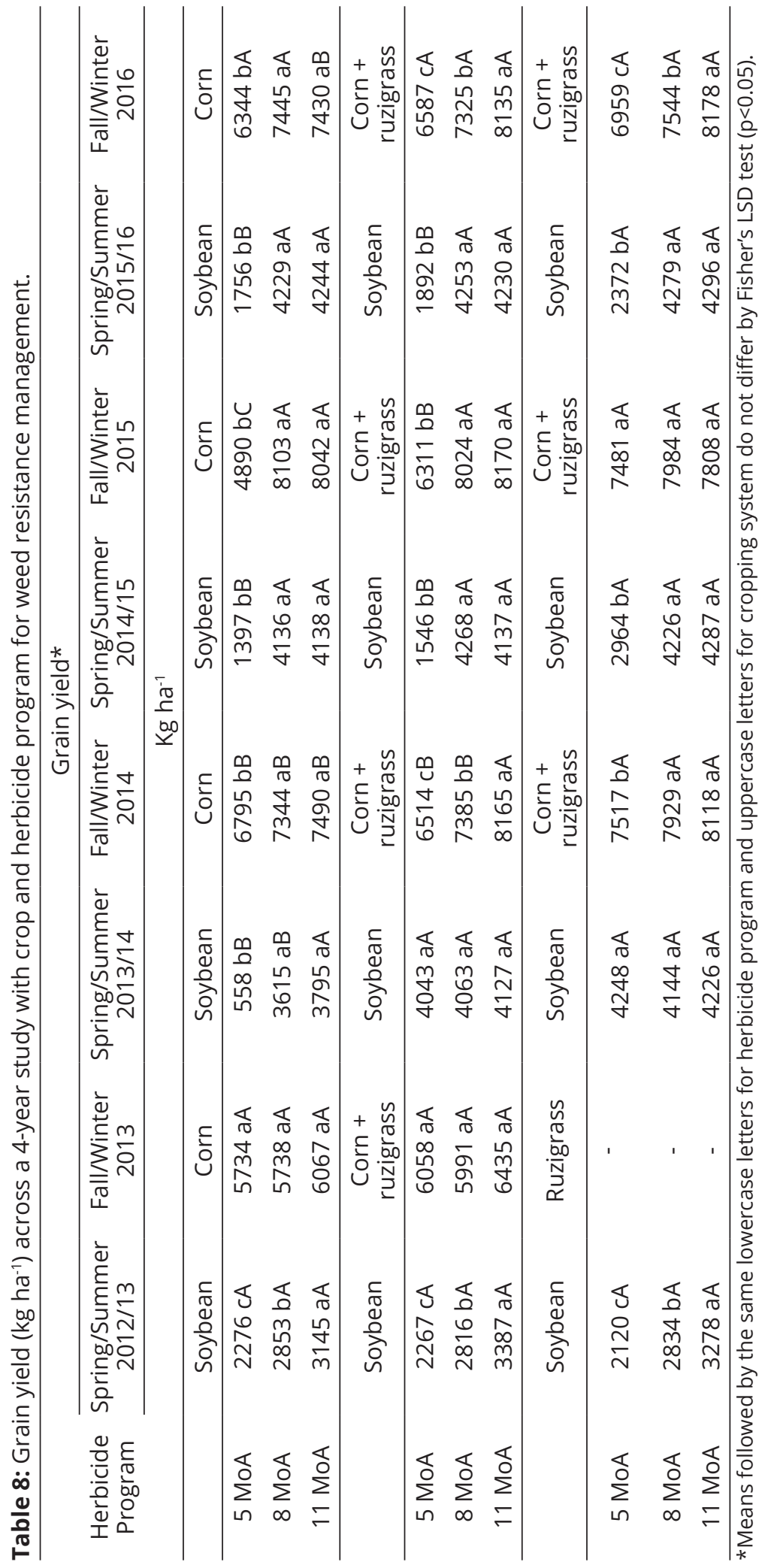


consider the widest possible variety of control methods for effective resistance management (Powles; Gaines, 2016).

\section{CONCLUSIONS}

The results obtained in this study support the hypothesis that using cover crop such as ruzigrass, associated with rotation of herbicide mechanisms of action, is strongly effective for managing glyphosate-resistant conyza and sourgrass. Ruzigrass weed suppression was stronger on conyza than sourgrass, whereas herbicide rotation controlled sourgrass better than conyza. In most cases, the use of one method alone was not completely effective, especially in long term; therefore, the management of these two species must consider both (herbicide rotation and mixture, and cover crop use) for mitigating resistance and preventing the selection of biotypes with multiple resistance.

\section{ACKNOWLEDGMENTS}

We thank Dr. Scott Nissen for his useful comments and suggestions on manuscript drafts. This research was funded by Monsanto Company. The authors declare no conflict of interest.

\section{REFERENCES}

BALDÉ, A. B. et al. Agronomic performance of no-tillage relay intercropping with maize under smallholder conditions in Central Brazil. Field Crop Research, 124(2011):240-251, 2011

BASCHEA, A. D. et al. Soil water improvements with the longterm use of a winter rye cover crop. Agricultural Water Management, 172(1):40-50, 2016

BECKIE, H. J. Herbicide-resistant weeds: Management tactics and practices. Weed Technology, 20(2):793-814, 2006.

BECKIE, H. J. Herbicide-resistant weed management: Focus on glyphosate. Pest Management Science, 67(2):1037-1048, 2011.

BECKIE, H. J.; REBOUD, X. Selecting for weed resistance: Herbicide rotation and mixture. Weed Technology, 23(3):363-370, 2009.

BORGHI, E. et al. Influência da distribuição espacial do milho e da Brachiaria brizantha consorciados sobre a população de plantas daninhas em sistema plantio direto na palha. Planta Daninha, 26(2):559-568, 2008.

BRENNAN, E. B.; SMITH, R. F. Winter cover crop growth and weed suppression on the central coast of California. Weed Technology, 19(4):1017-1024, 2005.
CARVALHO, L. B. et al. Detection of sourgrass (Digitaria insularis) biotypes resistant to glyphosate in Brazil. Weed Science, 59(2):171-176, 2011.

CASTAGNARA, D. D. et al. Taxa de semeadura de Brachiaria brizantha consorciada com milho na incidência de plantas daninhas. Revista Brasileira de Ciências Agrárias, 6(2):440-446, 2011.

CHIKOWO, R. et al. Integrated weed management systems allow reduced reliance on herbicides and long-term weed control. Agriculture, Ecosystems and Environment, 132(3):237-242, 2009.

DAVIS, A. S. Cover-crop roller-crimper contributes to weed management in no-till soybean. Weed Science, 58(2):300309, 2010.

DIGGLE, A. J.; NEVE, P. B.; SMITH, F. P. Herbicides used in combination can reduce the probability of herbicide resistance in finite weed populations. Weed Research, 43(3):371-382, 2003.

FERREIRA, D. F. Sisvar: A computer statistical analysis system. Ciência e Agrotecnologia, 35(6):1039-1042, 2011.

GEMELLI, A. et al. Aspectos da biologia de Digitaria insularis resistente ao glyphosate e implicações para o seu controle. Revista Brasileira de Herbicidas, 11(1):231240, 2012.

GEMELLI, A. et al. Estratégias para o controle de capimamargoso (Digitaria insularis) resistente ao glyphosate na cultura milho safrinha. Revista Brasileira de Herbicidas, 12(2):162-170, 2013.

HEAP, I. International survey of herbicide-resistant weeds. Available in: <http://www.weedscience.org> Access in: August, 02, 2018.

LOPEZ OVEJERO, R. F. et al. Frequency and dispersal of glyphosate-resistant sourgrass (Digitaria insularis) populations across Brazilian agricultural production areas. Weed Science, 65(1):285-294, 2017.

MAROCHIO, C. A. et al. Genetic admixture in species of Conyza (Asteraceae) as revealed by microsatellite markers. Acta Scientiarum, Agronomy, 39(2):437-445, 2017.

NORSWORTHY, J. K. et al. Reducing the risks of herbicide resistance: Best management practices and recommendations. Weed Science, 60(spe):31-62, 2012.

OLIVEIRA JUNIOR, R. S. et al. Grass biomass mulching to suppress emergence and early growth of weeds. Planta Daninha, 32(2):11-17, 2014. 
OLIVEIRA NETO, A. M. et al. Estratégias de manejo de inverno e verão visando ao controle de Conyza bonariensis e Bidens pilosa. Planta Daninha, 28(1):1107-1116, 2010.

PAIVA-FOLETTO, M. Allelopathic effects of Brachiaria ruziziensis and aconitic acid on Ipomoea triloba weed. Allelopathy Journal, 30(3):33-47, 2012.

PEACHEY, R. E. et al. Effect of cover crops and tillage system on symphylan (Symphlya: Scutigerella immaculata, Newport) and Pergamasus quisquiliarum Canestrini (Acari: Mesostigmata) populations, and other soil organisms in agricultural soils. Applied Soil Ecology, 21(2):59-70, 2002.

PETERSON, M. A. et al. The challenge of herbicide resistance around the world: A current summary. Pest Management Science, 75:112-121, 2017.

POWLES, S. B.; GAINES, T. A. Exploring the potential for a regulatory change to encourage diversity in herbicide use. Weed Science, 64(4):649-654, 2016.

POWLES, S. B. et al. Herbicide resistance: Impact and management. Advances in Agronomy, 58(1):57-93, 1997.
SANTOS, G. et al. Conyza sumatrensis: A new weed species resistant to glyphosate in the Americas. Weed Biology and Management, 14(1):106-114, 2014.

SIQUEIRA NETO, M. S. et al. Soil carbon stocks under no-tillage mulch-based cropping systems in the Brazilian Cerrado: An on-farm synchronic assessment. Soil Tillage Research, 110(4):187-195, 2010

TAKANO, H. K. et al. Spread of glyphosate-resistant sourgrass (Digitaria insularis): Independent selections or merely propagule dissemination? Weed Biology and Management, 18(3):50-59, 2018.

TREZZI, M. M. et al. Impact of Conyza bonariensis density and establishment period on soyabean grain yield, yield components and economic threshold. Weed Research, 55(2):34-41, 2015.

USDA. World Agricultural Production. Circular Series, WAP 03-17. Available in: <https://apps.fas.usda.gov/ psdonline/circulars/production.pdf> Access in: August, 01, 2018. 